Management Dynamics

Vol. 23, No. 2: 53-62, 2020

Shanker Dev Campus

Doi: https://doi.org/10.3126/md.v23i2.35807

\title{
Secondary Capital Market of Nepal: Assessing the Relationship Between Share Transaction and NEPSE Index
}

Dhan Raj Chalise*

\begin{abstract}
Capital Market plays a significant role in financial mobilization and provide an effective way of procuring long-term funds at same. In a addition it provide an investment opportunity for individuals and institutions. Nepalese capital market is growing and improving phase. The objective of this study is to assess the existing status of secondary capital market and to examine the relation between the share transaction amount and NEPSE Index. The period 2009/10 to 2018/19 has been used for study purpose. The trends of capital market development track after 2009/10 to present status has been indentified using descriptive analytical research design. Applying secondary data, the results found that there has significant contribution of secondary capital market for financial resources mobilization in Nepal. In addition, there exist significant positive impact of share transactions on NEPSE Index in Nepalese secondary capital market. The study recommends more effort form related sector for the modernization and systematization of share market.
\end{abstract}

Keywords: Capital market, financial mobilization, Secondary market, NEPSE Index.

\section{Introduction}

Capital market is specifically known as the stock market which the mobilizer of capital for economic development and the economic mirror of any economy. Capital market is where buying and selling of share happens. People can buy and sell shares as they want. Capital market plays a vital role in aiding the companies to raise capital for expansion and growth. Through IPOs, companies issues shares to the public and in turn receive funds that are used for various purposes. The company gets listed on the stock exchange after IPO and that provides an opportunity to a man to invest in the company. Capital market provides an opportunity to be a trader or investor in the share market. Traders hold stocks for a short period of time whereas investors hold stocks for a longer duration. As per financial needs, we can choose the investment product.

Obiakor and Okwu (2011) examined that relevant indicators of economic growth and performance of capital market, such as GDP, market capitalization value of shares traded foreign private investment and gross capital formation. Since the early 1990s, the Indian capital market has been transformed through a combination of sophisticated information technology,

* Lecturer, Shanker Dev Campus, PhD Scholar, Faculty of Management, Tribhuvan University, Nepal. 
strengthened regulatory structures, rapid evolution of market structures and willingness to accept foreign investment. This encouraged foreign investors and intermediaries to enter the market which led to higher standards (Torres, Wells \& Khan, 2013).

Nepal Stock Exchange (NEPSE) has been operating the secondary market under the Securities Act 2006. The goals and objectives are to enlist the publicly issued securities, provide liquidity in overall capital market by encouraging securities trading of listed government and organized companies through brokers, intermediaries and market makers and support overall development of country by increasing securities' transaction and reliable environment in capital market. The formal trading of secondary market in Nepal was started only in 1994 after the establishment of NEPSE. Initially, there were 62 companies with 25 brokers. The trading system was open outcry system. The most significant change in Nepalese secondary market was the establishment of semi-automated system in 24 August, 2007. Presently, NEPSE has increased the number of brokerage houses to 50 and more than 222 companies are listed. In the context of Nepal, the secondary capital market is growing phase; however there are various areas to expand and develop this according present needs.

\section{Statement of the Problem}

Ujunwa and Modebe (2012) has pointed that he capital market is one of the most vital areas of the economy as it provides companies access to capital and investors with a slice of ownership in the economy and the potential of gains based on company's future performance. The capital market establishes working relationships between the people engaged in saving, mobilization and investment capital. Similarly, capital market plays a significant role in the economy whereas it mobilizes the unproductive financial resource in productive sectors of the economy (NRB, 2012).

The secondary capital market of Nepal is growing phase but not playing the significant role for financial resources mobilization. In Nepal, an organized secondary capital market can serve as the medium for transferring part of the business ownership of foreign corporations to the citizens and if systematically organized it could be a source of the much needed capital necessary for economic growth (Adhikari, 2013). The capital market is influenced by non-economic parameters such as political, social, ethical as well other factors. This helps to mobilize the surplus unit to deficit unit for productive investments. Secondary capital markets mobilize the scattered resources and channels theming productive sector (Phuyal, 2016). In the context of Nepal, despite the history of decade of planned economics activities to develop real sector of a country, little attention was paid to the development of secondary capital market. This study is designed to answer the following questions.

- How is the present status of secondary capital market for financial resources mobilization in Nepal?

- To what extent is the relationship between share transaction amount and NEPSE Index? 


\section{Objectives of Research}

The major objective of the study is to examine the status of secondary capital market of Nepal with reference to Nepal Stock Exchange. The other specific objectives of the research are:

- To analyze the present status of secondary capital market for financial resources mobilization in Nepal.

- To examine the relationship between share transaction amount and NEPSE Index.

\section{Review of Literature}

Capital market plays a significant role in an economy that allows investor's fund to center point potential opportunity such as saving funds are mobilize and channeled efficiently to users. Capital market is assumed to be the barometer of the economy by which we can study the economic conditions of the country (Aggarwal, 2017). Thus, capital markets are a network specialized financial institutions, series of mechanism, processes and infrastructure that in various ways facilitate the bridging together of suppliers and users of medium to long-term capital. The capital markets play a significant role in the economy by mobilizing the funds (Pradhan, 1993).

The secondary capital market is where securities are traded after the company has sold its offering on the primary market. Small investors have a much better chance of trading securities on secondary market since they are excluded from IPOs (Augustine, 2012). Anyone can purchase securities on the secondary market as long as they are willing to pay the asking price per share. A broker basically purchases the securities on behalf of an investor in the secondary market where prices on the secondary market fluctuate with demand. Investors have to pay a commission to the broker for carrying out the trade (Khan, et. al., 2020). The secondary market has two different categories such as auction and dealer markets. The auction market is home to the open outcry system where buyers and sellers congregate in the one location and announce the prices at which they are willing to buy and sell their securities. In the dealer markets, people trade through electronic networks. Most of the small investor's trade through dealer markets (Bencivenga, et. al., 1996).

Development of stock market reflects the development of capital market. Linking equity market with the development of capital market has showed positive impact. Debt and equity markets help allocate capital within an economy (Dudley \& Hubbard, 2004). Asmed Saleem (2013) remarked that capital markets are a key component of national development, improving the mobilization of savings by providing alternative sources of financing for productive investments and supporting the development of long-term savings channels.

The capital market is unique in a country's financial system because of its peculiar function in the economy. Capital markets are a vital part of the financial development and economic development of a country (Sullivan, 1978). Development of capital market has been linked with the economic growth. Capital market plays crucial role in mobilization of domestic resources 
and channeling them efficiently to raise economic production and productivity (Lenee, \& Oki, 2017). The level of capital market development is thus an important determinant of a country' level of savings, efficiency and investment and ultimately its rate of economic growth. Thus, economic barometer that reflects the development of capital market in any country.

Gurung (2004) has concluded that securities market plays a significant role for mobilizing savings and channeling them in productive purposes by providing liquidity on securities so that it could be minimized the risk and maximizes the returns. The study on the securities market performance reveals that there was no synchronization among different securities market performance indicators, but it is true that they almost have depicted an erratic trend during the study periods. He has pointed that the size of securities market is very small and the liquidity of securities has also found poor (Samitas, 2004).

The Securities Board of Nepal (SEBON) is the government body that regulates the capital market under the Securities Act 2006. The functions of SEBON are to issues necessary securities regulations and directives, register the securities of public companies, regulate and systematize the issue, transfer, sale and exchange of the registered securities among others. The establishment of the Nepal Stock Exchange (NEPSE), the sole stock exchange of Nepal where we can buy and sell shares in the secondary market, opened an avenue for investors both large and small to invest in enterprises operating in various sectors. This also provided enterprises with an opportunity to obtain capital which is indispensable to any business. The trading of listed securities at stock exchanges, often known as secondary capital market transactions is new for Nepal.

The investors in the company can use this investment to fulfill their life goals. Capital market is the major platforms for investment as it provides liquidity whereas we can buy and sell share anytime based on the need. People are investing in the share market for dividends, capital growth and buyback purposes (Stoica, 2002). Above literature indicates that the expansion and achievement the sustainable growth of economy, investor awareness and their commitment for the long-term investment play the vital role. It was expected that the awareness and the commitment move in the same direction and their association contributes a lot to the economic development.

\section{Research Methodology}

This study is based on secondary data and descriptive research design has been used. Data published by different resources such as Economic Survey, Ministry of Finance, Quarterly Bulletin, NRB and Reports publish SEBON and Nepal Stock Exchange etc. were the major sources of statistical information. For analyzing and interpreting the data collected through the different sources in the process of presentation and analysis, both the qualitative and quantitative parameters have been used. 


\section{Model Specification}

The following equations are used to estimate the impact of secondary capital market on different macroeconomic variables:

The impact of share transaction amount (STA) on NEPSE is estimated by:

NEPSE $=\alpha_{0}+\beta_{1}$ STA $+\varepsilon$

Where, NEPSE is generated due to share transaction amount in share market, STA is the share transaction amount. The $\alpha_{0}$ is constant, $\beta_{1}$ is coefficient parameter. NEPSE is expected to be determined due to share transaction amount in share market. For analyzing and interpreting the data collected through the different sources in the process of presentation and analysis, both the qualitative and quantitative parameters have been used. Data are also presented in tables, graphs and diagrams as required.

\section{Result and Discussion}

In the secondary capital market context, the number of companies listed in Nepal Stock Exchange Limited has reached to 212 in mid-March 2020. The stock market capitalization increased by 24.7 percent to Rs. 1760.93 billion in mid-March 2020 compared to mid-Mach 2019. Up to the mid-March 2020, the number of depository members registered in CDS has reached 75 and the depository members have been providing deposit service from 77 districts. The number of dematerialized securities has reached 5.20 billion in mid-March 2020 which was Rs. 4.12 billion in the corresponding period of the previous year.

Table 1: Position of Secondary Capital Market (Rs. in Ten Million)

\begin{tabular}{|l|c|c|c|c|c|}
\hline \multirow{2}{*}{ Details } & \multicolumn{5}{|c|}{ Fiscal Years } \\
\cline { 2 - 6 } & $\mathbf{2 0 1 4 / 1 5}$ & $\mathbf{2 0 1 5 / 1 6}$ & $\mathbf{2 0 1 6 / 1 7}$ & $\mathbf{2 0 1 7 / 1 8}$ & $\mathbf{2 0 1 8 / 1 9}$ \\
\hline Share Transaction Amount & 6533.15 & 16395.77 & 20478.81 & 12129.96 & 11006.70 \\
\hline No. of Transaction (000) & 159717.47 & 302021.00 & 392598.20 & 293694.60 & 387465.80 \\
\hline No. of Listed Companies & 232 & 229 & 208 & 196 & 215 \\
\hline $\begin{array}{l}\text { Types of Share Transaction } \\
\text { (Script Traded) }\end{array}$ & 271 & 274 & 270 & 259 & 277 \\
\hline NEPSE Index (at Point) & 961.23 & 1718.15 & 1582.67 & 1212.36 & 1259.02 \\
\hline
\end{tabular}

Source: Economic Survey 2019/20 *Base year 1992/93.

Table-1 depicts the status of secondary capital market from 2014/15 to 2018/19. The share transaction amount was Rs.6533.15 ten million in 2014/15 whereas it was Rs.11006.70 ten million in 2018//19. The number of transaction was 159717.47 thousand in 2014/15 whereas these number increased to 387465.80 thousand in 2018/19. There were 232 listed companies in 2014/15 whereas there were 215 listed companies in 2018/19. The NEPSE index was 961.23 points in 2014/15 whereas it was 1259.02 points in 2018/19. 
The Share market is growing phase of Nepal since 2000s. There has been significant progress of share transaction and NEPSE index in Nepal. The share transaction amount has been increasing trends in the most of years. The NEPSE point value has been fluctuating trends after 2000s.

Table 2: Status of Share Transaction Amount, NEPSE and GDP (\%) (Rs. in Ten Million)

\begin{tabular}{|c|c|c|c|}
\hline \multirow[t]{2}{*}{ Year } & \multicolumn{2}{|c|}{ Secondary Market } & \multirow{2}{*}{$\begin{array}{c}\text { \% of Market Capitalization } \\
\text { in GDP }\end{array}$} \\
\hline & Share Transaction Amount & NEPSE Index & \\
\hline $2009 / 10$ & 1185.11 & 477.73 & 32.15 \\
\hline $2010 / 11$ & 666.53 & 362.85 & 19.48 \\
\hline $2011 / 12$ & 1027.28 & 389.74 & 23.41 \\
\hline $2012 / 13$ & 2204.88 & 518.33 & 30.24 \\
\hline $2013 / 14$ & 7729.85 & 1036.11 & 40.00 \\
\hline $2014 / 15$ & 6533.15 & 961.23 & 46.5 \\
\hline $2015 / 16$ & 16395.77 & 1718.15 & 84.1 \\
\hline 2016/17 & 20478.81 & 1582.67 & 69.4 \\
\hline $2017 / 18$ & 12129.96 & 1212.36 & 47.1 \\
\hline 2018/19 & 11006.7 & 1259.02 & 45.3 \\
\hline
\end{tabular}

Source: Economic Surveys 2010/11 to 2019/20.

Table-2 depicts that status of share market of Nepal from 2009/10 to 2018/19. The share transaction amount takes significant position of Nepal for financial mobility and economic growth and development of Nepal. The share transaction amount was Rs.1185.11 crore in 2009/10 in 2009/10 whereas it was Rs.11006.7 crore in 2018/19. The lowest point of NEPSE was 477.73 in 2009/10 whereas the highest point was 1718.15 in 2015/16. There has been significant contribution of market capitalization in the GDP percentage and GDP falls between 7.72 to 84.1 percent during the study period.

The percentage trends of market capitalization in GDP from 2009/10 to 2018/19, effects the contribution of share capitalization percentage in GDP seems to be increasing and dressing trends in different time intervals in the study periods.

Table 2 also depicts that the trends of NEPSE index from 2009/10 to 2018/19. The NEPSE index trends line is increasing and decreasing direction in the study periods. The value of NEPSE was minimum in 2010/11 whereas it was maximum in 2015/16. 


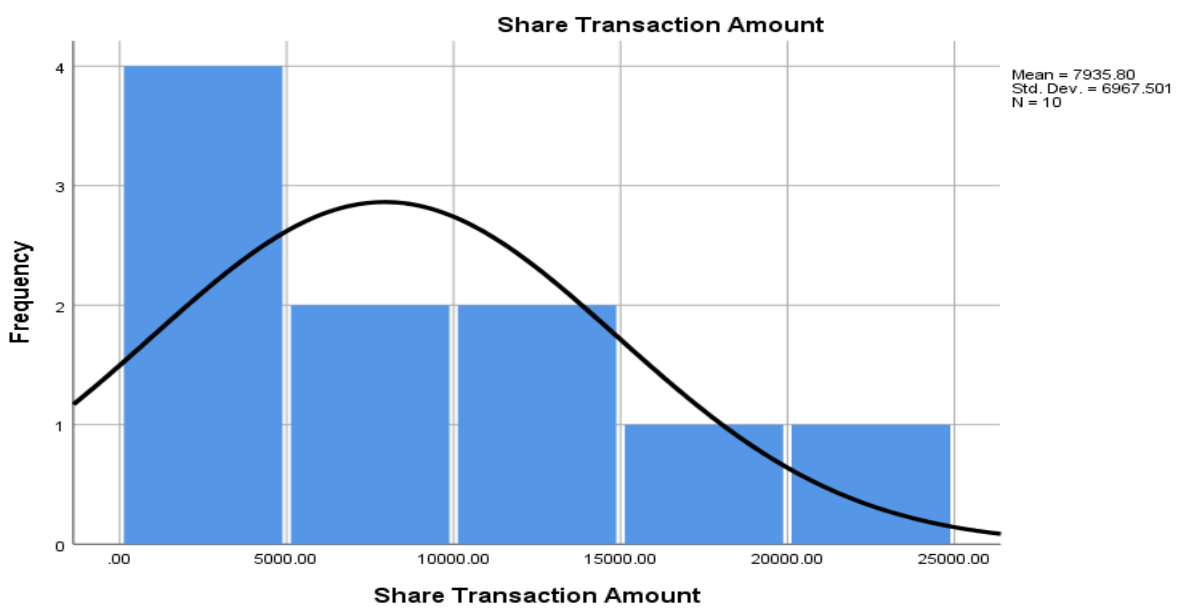

Figure-1: Histogram of Share Transaction Amount Source: Table-2.

Figure-1 indicates the share transaction in secondary market in capital market. The mean values have been found 7935.80 and standard deviation value of 6967.501. It indicates that data are more scatters.

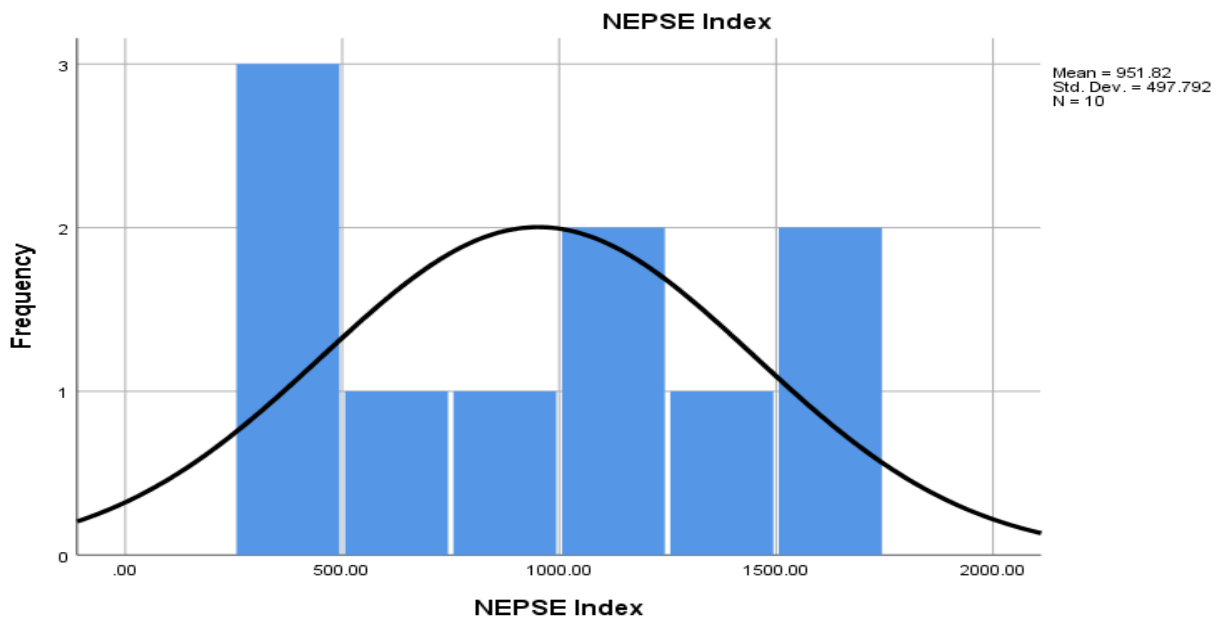

Figure -2: Histogram of NEPSE in Capital Market

Source: Table-2.

Figure-2 represents the NEPSE index in secondary capital market where the mean value was 951.82 and standard deviation (Std.Dev.) was 497.792 in the study periods. The value of Std. Dev. is less than the value of mean value which indicates that data are closure to each other's. 


\section{Impact of Share Transaction on NEPSE Index}

There has been significant contribution of share transaction on NEPSE index. The value of NEPSE point has determined by the share transaction amount. Empirical evidence shows that share transaction amount has positive impact on NEPSE index. By using data of 2009/10$2018 / 19$, this study finds that the relationship share transaction amount and NEPSE index is found positive.

Table3: Regression between Share Transaction in Secondary Market and NEPSE Index

\begin{tabular}{|c|c|c|c|c|c|c|}
\hline \multicolumn{7}{|c|}{ Coefficients $^{a}$} \\
\hline & & \multirow{2}{*}{\multicolumn{2}{|c|}{$\begin{array}{c}\text { Unstandardized } \\
\text { Coefficients }\end{array}$}} & \multirow{3}{*}{$\begin{array}{c}\text { Standardized } \\
\text { Coefficients } \\
\text { Beta }\end{array}$} & \multirow[b]{3}{*}{$\mathrm{t}$} & \multirow[b]{3}{*}{ Sig. } \\
\hline & & & & & & \\
\hline \multicolumn{2}{|c|}{ Model } & B & Std. Error & & & \\
\hline \multirow[t]{4}{*}{1} & (Constant) & 402.367 & 64.353 & & 6.253 & .000 \\
\hline & Share & .069 & .006 & .969 & 11.112 & .000 \\
\hline & Transaction & & & & & \\
\hline & Amount & & & & & \\
\hline \multicolumn{7}{|c|}{ 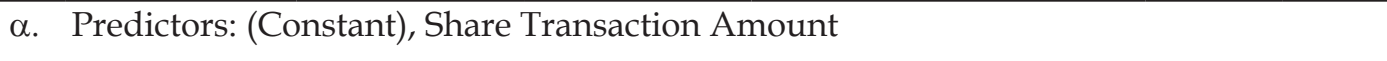 } \\
\hline \multicolumn{7}{|c|}{ ß. $\quad$ Dependent Variable: NEPSE Index } \\
\hline
\end{tabular}

Table 3 shows the regression coefficient with $t$ and $p$ value of model estimate. In the regression analysis, the relationship has been analyzed between the share transaction amount and NEPSE index. The result seems to be valid as the diagnostic parameters justified the relationship such as the regression coefficient is significant at 5 percent level of significance.

Table 4: Model summary statistics of the study

\begin{tabular}{|l|c|c|c|c|}
\hline \multicolumn{5}{|c|}{ Model Summary } \\
\hline Model & $\mathrm{R}$ & R Square & Adjusted R Square & $\begin{array}{c}\text { Std. Error of the } \\
\text { Estimate }\end{array}$ \\
\hline 1 & $.969^{\mathrm{a}}$ & .939 & .932 & 130.24127 \\
\hline
\end{tabular}

Table 4 represents regression model summery under study. Model summary shows that the value $R$ square 0.939 which is highly sufficient to fit the goodness of model fit. Hence model indicates that there is significant impact of share transaction amount on NEPSE index of Nepal.

\section{Conclusion and Implications}

Secondary capital market of Nepal has not been well developed. There is state owned stock exchange system, has neither been modernized nor has the market been fully modernized. The share market demands one more stock exchange in the corporate private sector is strongly needed as mentioned in SEBON's approved policy and program to minimize the monopolistic 
situation. The modern stock exchange could see a major breakthrough in daily share-trading. The NEPSE index could not become a true economic mirror and indicator because the role of real sector seems to be insignificant. To encourage the real sector companies in the share market, different measures must be taken such as high tax rebate, putting the sector in the priority list of the central bank and adoption of the international system of free pricing based on book building.

Even today, Nepal has been practicing the traditional fixed pricing system in IPO since the beginning. SEBON should introduce the latest system without delay in phase-wise manner. Modernization of the share market has just beginning but needs more improvement. The paces of reviving the economy and structurally reforming will lead to stability and complete modernization of the Nepalese share market.

\section{References}

Adhikari, N. (2013). Capital market development in Nepal. In Reshaping Organizations to Develop Responsible Global Leadership-Conference Proceedings, 1(1), 321-334.

Aggarwal, R. (2017). Different avenues of capital market (secondary market) available for investing in market of Yamuna Nagar. International Research Journal of Management, IT and Social Sciences, 4(3), 34-50.

Augustine, U. J. U. N. W. A. (2012). Adopting strategic management approach in the capital market development: The Nigerian Case. International Journal of Economics and Finance, 4(1).

Bencivenga, V. R., Smith, B. D., \& Starr, R. M. (1996). Liquidity of secondary capital markets: Allocative efficiency and the maturity composition of the capital stock. Economic Theory, 7(1), 19-50.

Gurung, J.B. (2004). Growth and Performance of Securities Market in Nepal. The Journal of Nepalese Business Studies, 1(1), 85-92.

Khan, M. Y., Javeed, A., Cuong, L. K., \& Pham, H. (2020). Corporate governance and cost of capital: Evidence from emerging market. Risks, 8(4), 104.

Lenee, T. L., \& Oki, J. (2017). Capital market development and economic growth: Evidence from the MINT countries. Journal of Economics and Sustainable Development, 8(2), 68107.

Ministry of Finance (2010). Economic Survey 2010/11. Kathmandu: Government of Nepal. Ministry of Finance. (2014). Economic Survey 2014/15. Kathmandu: Government of Nepal. Ministry of Finance. (2019). Economic Survey 2019/20. Kathmandu: Government of Nepal. NRB (2012). Annual Reports 2010-11. Kathmandu: Nepal Rastra Bank: Central Office, $29^{\text {th }}$ August, 2012. 
Obiakor, R. T., \& Okwu, A. T. (2011). Empirical analysis of impact of capital market development on Nigeria's economic growth (1981-2008) (Case Study: Nigerian Stock Exchange). DLSU Business \& Economics Review, 20(2), 79-96.

Phuyal, N. (2016). Can macroeconomic variables explain long term stock market movements? A study of Nepali capital market. Journal of Business and Management Research, 1(1), 26-38.

Pradhan, R.S., (1993). Stock market behavior in a small capital market: A case of Nepal. Nepalese Management Review, 20-32.

Romero-Torres, J., Wells, S., \& Selwyn-Khan, S. (2013). Development of capital markets in member countries of the South Asian Association for Regional Cooperation.

Samitas, A. G. (2004). Testing the efficient market hypothesis in the Greek secondary capital market. Zagreb International Review of Economics \& Business, 7(1), 23-38.

Stoica, O. (2002). The role of the capital market in the economic development. Available at SSRN 951278.

Sullivan, T. G. (1978). The cost of capital and the market power of firms. The Review of Economics and Statistics, 209-217. 